\title{
MIR199A2 Pre-miRNA
}

National Cancer Institute

\section{Source}

National Cancer Institute. MIR199A2 Pre-miRNA. NCI Thesaurus. Code C82798.

MIR199A2 pre-miRNA is an oligoribonucleotide that is encoded by the human MIR199A2 gene and has a role in the regulation of gene expression. 